\title{
A case with angina bullosa hemorrhagica
}

\section{Anjina bülloza hemorajika: Bir olgu}

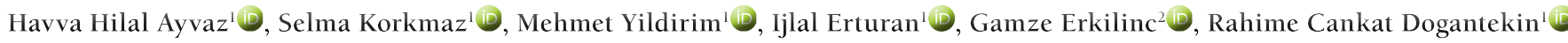 \\ ${ }^{1}$ Dept. of Dermatology, Suleyman Demirel University Faculty of Medicine, Isparta, Turkey, ${ }^{2}$ Dept. of Pathology, Suleyman Demirel University \\ Faculty of Medicine, Isparta, Turkey
}

\begin{abstract}
Angina bullosa hemorrhagica $(\mathrm{ABH})$ is an idiopathic benign condition in which hemorrhagic bullae develop mostly in the oral mucosa without any vesiculobullous diseases or blood dyscrasias. A 42-year-old female patient was admitted to our clinic with a sudden blood-filled blister in the mouth. A bright, tense-surfaced hemorrhagic bulla, approximately $1 \mathrm{~cm}$ in size, was observed in the patient's sublingual mucosa. Despite no clear etiology of this disease, there are triggering conditions of $\mathrm{ABH}$ such as trauma, deterioration in collagen production after long-term steroid inhaler use, diabetes mellitus, and hypertension. The lesions seen on the soft palate are usually painless, tense, and appear as dark red or purple blisters which rupture spontaneously within 24-48 hours. This case is presented in terms of being more common than expected and being a differential diagnosis with many diseases.
\end{abstract}

Key words: angina bullosa hemorrhagica, blister, oral

O̊zet

Anjina bülloza hemorajika $(\mathrm{ABH})$ altta yatan vezikülobüllöz bir hastalık veya kan diskrazisi olmadan, oral mukozada hemorajik büllerle karakterize idiopatik benign bir durumdur. 42 yaşında kadın hasta, ağız içinde aniden gelişen kanla dolu kabarcık nedeniyle kliniğimize başvurdu. Hastanın sublingual mukozasında, yaklaşık $1 \mathrm{~cm}$ boyutunda, parlak, gergin yüzeyli hemorajik bir bül görüldü. Hasta bu durumun daha önceden de iki kez oluştugunu ve bir hafta içinde kendiliğinden iyileştiğini belirtti. Hastalığın patogenezi bilinmese de, ABH'de tetikleyici olarak düşünülen başlıca durumlar travma, uzun dönem inhaler steroid kullanımı sonrası kollajen yapımında bozulma, diabetes mellitus ve hipertansiyondur. Lezyonlar genellikle yumuşak damakta, ağrısız, gergin ve 24-48 saatte kendiliğinden rüptüre olan koyu kırmızı veya mor büller şeklinde görülür. Bu olgu, hastalığın düşünülenden daha sık bir antite olması ve birçok hastalıkla ayırıcı tanıya girmesi açısından sunulmuştur.

Anahtar kelimeler: anjina bülloza hemorajika, bül, oral

Corresponding author: Havva Hilal Ayvaz, Çünür Mah 5483 Cd. Çeliktepe-2 Sitesi C Blok No:20 Isparta,Turkey

Phone: +905309505907, Email: drhhilalayvaz@gmail.com

Received: 9 October 2020 Accepted: 13 December 2020

Conflicts of Interest: None

Funding: None

How to cite this article: Ayvaz HH, Korkmaz S, Yildirim M, Erturan I, Erkilinc G, Dogantekin RC. A case with angina bullosa hemorrhagica. Mucosa 2020;3:110-112

(c) (i) (5) This work is licensed under a Creative Commons Attribution-NonCommercial 4.0 International License. 


\section{Introduction}

Angina bullosa hemorrhagica $(\mathrm{ABH})$ is an idiopathic benign condition in which hemorrhagic bullae develop in the oral mucosa without any underlying vesiculobullous disease or blood dyscrasias. ${ }^{1}$ Herein, a 42-year-old female patient with $\mathrm{ABH}$ without any symptoms is presented.

\section{Case report}

A 42-year-old female patient was admitted to our clinic with a sudden bleb filled with blood in the mouth. There was no remarkable situation in the medical history of the patient. In the dermatological examination of the patient who do not have any symptoms, a hemorrhagic bulla with a shiny, tense surface, approximately $1 \mathrm{~cm}$ in size, was observed in the anterior region of the sublingual mucosa (Fig. 1). The patient stated that

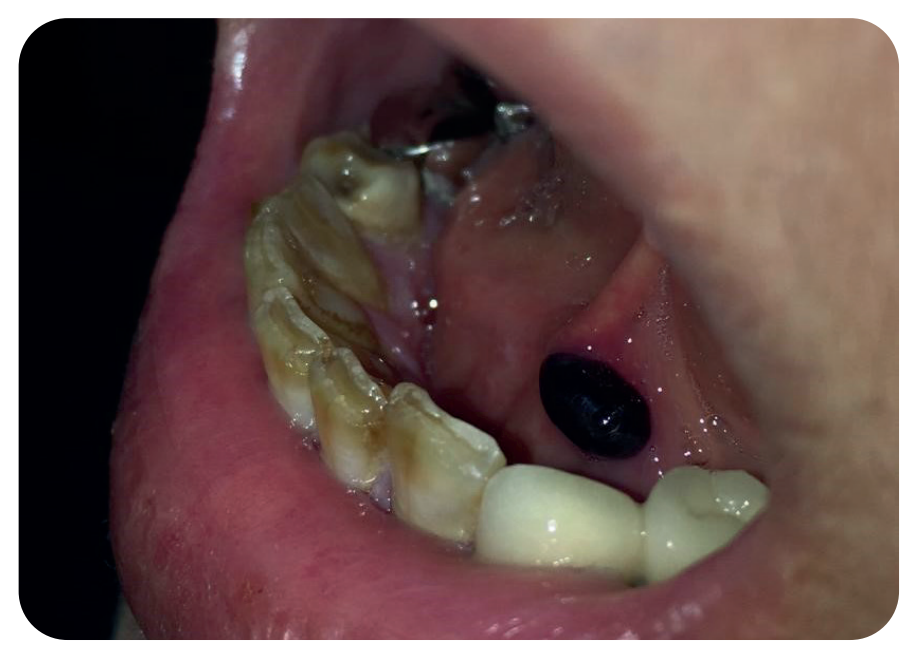

Fig. 1. A hemorrhagic bulla with a shiny and tense surface

similar blood-filled bubbles had occurred in different parts of the oral mucosa twice before, and those lesions healed spontaneously in a week. The patient's complete blood count, erythrocyte sedimentation rate, biochemistry and coagulation tests were normal. As a result of the biopsy procedure performed with the consent of the patient, an intraepithelial dissociation with fibrin deposition was observed, but there was no prominent inflammation suggesting autoimmune blistering disease (Fig. 2). The patient was diagnosed

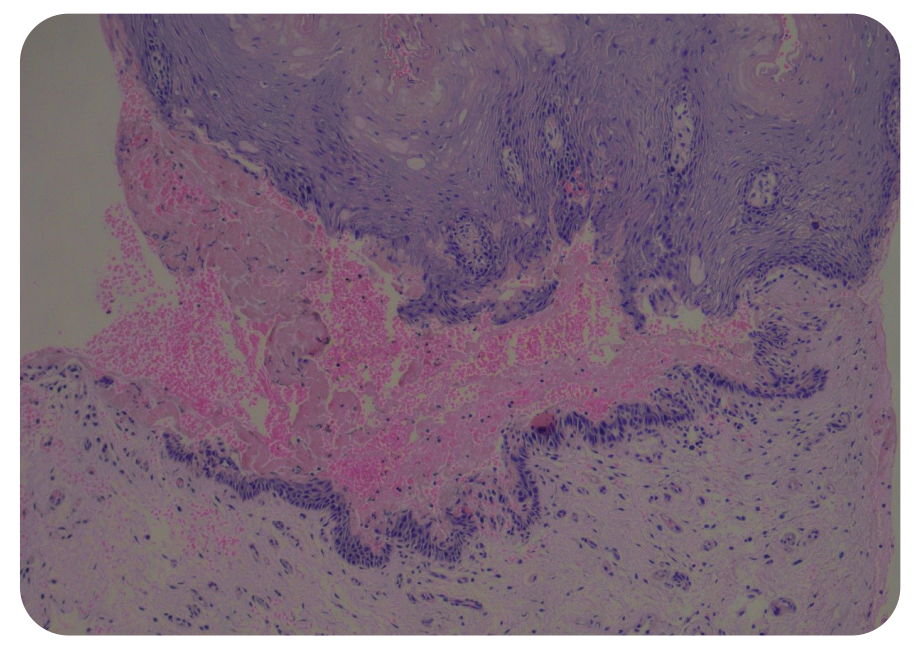

Fig. 2. An intraepithelial dissociation with fibrin deposition (H\&E x100)

with $\mathrm{ABH}$ in the light of clinical and histopathological findings. Chlorhexidine mouthwash was given to the patient, and was advised to avoid hard foods and hot drinks. In the follow-up after a week, the lesion regressed.

\section{Discussion}

The exact pathogenesis of $\mathrm{ABH}$ is unknown. ${ }^{1}$ On the other hand, there are triggering conditions of $\mathrm{ABH}$ such as trauma, deterioration in collagen production after long-term inhaler steroid use, diabetes mellitus and hypertension. Similar cases with unknown cause have been reported, as in our patient. The lesions seen on the soft palate are usually painless, tense, and appear as dark red or purple blisters and rupture spontaneously within 24-48 hours. ${ }^{3}$ Minimal infiltration and subepidermal bullae may be observed in the histopathology. In our case, the blistering was intraepithelial. $\mathrm{ABH}$, a condition that often affects middle-aged adults and does not show gender difference. It may be confused with vesiculobullous diseases, especially pemphigus vulgaris, bullous lichen planus, erythema multiforme, and fixed drug eruption. ${ }^{4}$ In addition, vasculitis, leukemia and other hematological diseases may be presented with hemorrhagic bullae. In this case, histopathological findings also supported $\mathrm{ABH}$.

This condition, which can be recurrent in up to $30 \%$ of patients, does not need any treatment, but symptoma- 
tic treatment may be given as well. ${ }^{4}$ Recognizing this disease, which is differentially diagnosed with many diseases, may prevent further investigations and treatments. $^{5}$

\section{References}

1. Karakas M, Akman A, Durdu M, et al. Two case with angina bullosa hemorrhagica. Turkderm 2004;38:75-7.

2. Horie N, Kawano R, Inaba J, et al. Angina bullosa hemorrhagica of the soft palate: a clinical study of 16 cases. J Oral Sci 2008;50:33-6.

3. Supekar BB, Sawatkar G, Wankhade VH. Angina bullosa hemorrhagica. Indian Dermatol Online J 2019;10:89.

4. Martini MZ, Lemos CA Jr, Shinohara EH. Angina bullosa hemorrhagica: report of 4 cases. Minerva Stomatol 2010;59:139-42.

5. Cinar SL, Kartal D, Canoz O, Borlu M, Ferahbas A. Case Report: A rare cause of oral bullae: Angina bullosa hemorrhagica. F1000Res 2017;6:1974. 